\title{
Sakarya İlinde Hepatit C Virüs Genotip Dağılımı; Üç Yıllık Retrospektif Çalışma
}

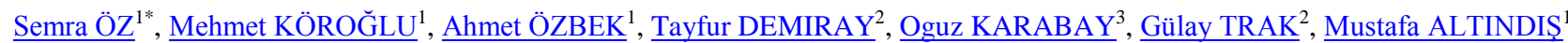

\begin{abstract}
Öz
HCV genotiplerinin belirlenmesi antiviral tedavi seçiminde, tedavinin planlanması ve tedaviye yanıtın öngörülmesinde yol göstericidir. Bu çalıșmada retrospektif olarak HCV genotip dağılımının belirlenmesi amaçlanmıştır. Çalışmada Ocak 2015-Aralık 2017 tarihleri arasında Sakarya Üniversitesi Tıbbi Mikrobiyoloji Laboratuvarına HCV genotip tayini amacıyla gönderilen 235 hastanın serum örneği çalışma grubunu oluşturdu. Örneklerden RNA izolasyonu üretici firmanın önerileriyle otomatik izolasyon sistemi (QIAsymphony, Qiagen, Almanya) ile yapıldı. Çalışma grubu; $105(\% 44,7)$ erkek, $130(\% 55,3)$ kadın olmak üzere toplam 235 hastadan oluștu. Genotip dağılımları; örneklerden 200'ü (\%85,1) tip 1, 2'si $(\% 0,9)$ tip 2,20 'si $(\% 8,5)$ tip 3, 7'si $(\% 3,0)$ tip 4 ve 6 's $(\% 2,6)$ mix tip (tip $1 \mathrm{a}+$ tip 1 b) idi. Genotip 1 içinde 13 '̈̈ $(\% 5,5)$ tip 1a, 182'si $(\% 77,4)$ tip 1 b iken, $5(\% 2,1)$ örnekte alt tip belirlenemedi. Kadınlarda genotip 1 b görülme sıklığı erkeklere göre anlamlı olarak yüksekti $(p=0,009)$. Genotip 1b saptanan hastaların yaş ortalaması diğer genotiplere sahip hastalara göre anlamlı olarak yüksekti $(\mathrm{p}<0,001)$. Yıllara göre tiplb dağılımında anlamlı bir değişiklik saptanamadı $(p=0,376)$. Sonuç olarak çalışmamızda; bölgemizdeki örneklerin çoğunluğunda genotip 1, alt tipin ise tip 1b olduğu belirlenmiştir. Genotip 1'den sonra en s1k, genotip 3 saptanmıştır. Klinik sürecin takibi ve antiviral tedavi seçiminde genotip belirlenmesinin yo gösterici olmasından dolayı bu çalışmaların HCV tedavisine önemli katkıları olacağ düşünülmektedir.
\end{abstract}

Anahtar kelimeler: Hepatit C virüs, genotip dağılımı, RNA
Yayın Bilgisi

Gönderi Tarihi: 07.11.2018

Kabul Tarihi: 14.12.2018

Online Yayın Tarihi: 31.12 .2019

DOI: $10.26453 /$ otjhs.480164

Sorumlu Yazar Semra ÖZ

Arabacialanı mahallesi 529.sokak No 22/1

Serdivan/SAKARYA

Tel: 05320530546

E mail: drsemragurel@hotmail.com

\section{Hepatitis C Virus Genotype Distribution in Sakarya Province; Three-Year Retrospective Study}

\section{$\underline{\text { Semra ÖZ }}^{1 *}, \underline{\text { Mehmet KÖROĞLU }}^{1}, \underline{\text { Ahmet ÖZBEK }}^{1}, \underline{\text { Tayfur DEMIRAY }}^{2}, \underline{\text { Oguz KARABAY }}^{3}, \underline{\text { Gülay TRAK }}^{2}, \underline{\text { Mustafa ALTINDIS }}^{1}$}

\begin{abstract}
The determination of HCV genotypes in the selection of antiviral therapy is helpful in planning treatment and predicting response to treatment. The aim of this study was to determine the HCV genotype distribution retrospectively. The study group consisted of 235 patients who were referred to Sakarya University Medical Microbiology Laboratory for the determination of HCV genotype between January 2015 and December 2017. The isolation of RNA from the samples was made by the manufacturer with automatic isolation system (QIAsymphony, Qiagen, Germany). The study group; 105 (44.7\%) males and 130 (55.3\%) females, a total of 235 patients. Genotype distributions; 200 of the samples $(85.1 \%)$ were type $1,2(0.9 \%)$ type $2,20(8.5 \%)$ type $3,7(3.0 \%)$ type 4 and $6(2.6 \%)$ mix type (type $1 \mathrm{a}+$ type $1 \mathrm{~b})$. In genotype $1,13(5.5 \%)$ were type $1 \mathrm{a}$ and $182(77.4 \%)$ were type $1 \mathrm{~b}$. The prevalence of genotype $1 \mathrm{~b}$ was significantly higher in women than in men $(\mathrm{p}=0.009)$. The mean age of patients with genotype $1 \mathrm{~b}$ was significantly higher than patients with other genotypes $(p<0.001)$. There was no significant change in the distribution of type $1 b$ according to years $(p=0.376)$. In our study; Genotypes were found in the majority of the samples in our region and type $1 \mathrm{~b}$ in the subtype. Genotype 3 was the most common type after genotype 1 . These studies are expected to contribute significantly to the treatment of $\mathrm{HCV}$ because of the guiding nature of the genotype in the selection of antiviral treatment and clinical follow-up.
\end{abstract}

Keywords: Hepatitis C virus, genotype distribution, RNA

Article Info
Received: 07.11 .2018

Accepted: 14.12.2018

Online Published: 31.12 .2019

DOI: $10.26453 /$ otjhs. 480164

\section{Corresponding Author} Semra ÖZ

Arabacialanı mahallesi 529. sokak No 22/1

Serdivan/SAKARYA

Tel: 05320530546

E mail:: drsemragurel@hotmail.com

\section{GíRiş}

Hepatit C virüsü (HCV) kronik hepatit, siroz ve hepatoselüler karsinomanın en önemli nedenlerinden olup dünyadaki ciddi sağlık sorunları arasında gösterilmektedir. ${ }^{1-3}$ Bazı tahminlere göre, dünya genelinde her yll 3-4 milyon insan yeni enfekte oluyor ve $\mathrm{HCV}$ ile 
ilişkili bozukluklardan dolayı yılda 350.000'den fazla kişi ölüyor. ${ }^{4}$ HCV seroprevalansinın son 15 yilda $\% 2,8$ 'den fazla yükseldiği ki bunun da 185 milyondan fazla enfeksiyona denk geldiği bildirilmektedir. ${ }^{2}$ HCV yüksek derecede genetik çeşitliliğe sahiptir. ${ }^{5}$ HCV'nin yedi major genotipi ve her bir genotipte ayrıca 67 doğrulanmış ve 20 geçici alt tipi bulunmaktadır. ${ }^{6} \mathrm{HCV}$ genotiplerinin coğrafi dağılımı geniş ölçüde değişmektedir. Fakat genotip 1, en yaygın görülen genotiptir. Genotip 1'in en sık görülen alt tipi de genotip 1b'dir. HCV genotip dağılımının global olarak değerlendirildiği bir çalışmada genotip 1'in tüm dünyada en fazla görüldügünü ve yaklaşık \%46 civarında olduğu belirtilmiştir. Aynı çalışmada Türkiye için genotip 1'in \%90'nın üzerinde bir paya sahip olduğu bildirilmiştir. ${ }^{7}$ Genotip 1'den sonra en s1k görülen genotip ise genotip 3'tür. Fakat bazı bölgelerde genotip 4, 5, 6'nın daha baskın olduğu görülmektedir. ${ }^{7,8}$ Ülkemizde farklı bölgelerde yapılan bazı çalışmalarda da dünyadaki dağılıma benzer şekilde genotip $1 \mathrm{~b}$ görüldüğü bildirilmiştir. ${ }^{9-11}$ Farklı genotiplerin belirlenmesi antiviral tedavi seçiminde, tedavinin planlanması ve tedaviye yanıtın öngörülmesinde yol göstericidir. HCV genotip 1 ve 4 'ün genotip 2 ve 3'e göre tedaviye daha dirençli olması, tedavi süresini ve dozunu değiştireceğinden tedaviye başlamadan genotip tayininin yapılması önemlidir. ${ }^{12}$
$\mathrm{Bu}$ çalışmada retrospektif olarak HCV genotip dağılımının belirlenmesi amaçlanmıştır.

\section{MATERYAL VE METOD}

Çalışma için Sakarya Üniversitesi Tıp Fakültesi tarafindan Etik Kurul onayı alındı (71522473/050.01.04/276 say1 ve 23.11.2018 tarihli). Çalışmada Ocak 2015-Aralık 2017 tarihleri arasında Sakarya Üniversitesi Tibbi Mikrobiyoloji Laboratuvarına HCV genotip tayini amacıyla gönderilen 235 hastanın serum örneği çalışma grubunu oluşturdu. Örneklerden RNA izolasyonu üretici firmanın önerileriyle otomatik izolasyon sistemi (QIAsymphony, Qiagen, Almanya) ile yapıldı. Genotip analizi, HCV genomlarının önce iki bölgesi PCR ile çoğaltıldı, sonra $5^{\prime}$ UTR bölgesine ait 3 primer ve core bölgesine ait 1 primer kullanılarak dizilendi. Dizilemede Pyrosequensing yöntemi ve "PyroMark Q24 Workstation" (QIAgen, Almanya) kullanıldı. Veriler SPSS 20 istatistik programında değerlendirildi. Değişkenler ortalama \pm standart sapma veya frekans (yüzde) olarak verildi. Kategorik değişkenlerin değerlendirilmesinde $\mathrm{Ki}$ kare analizi kullanıldı. Anlamlılık düzeyi olarak $\mathrm{p}<0,05$ kabul edildi.

\section{BULGULAR}

Çalışma grubu; 105 (\%44,7) erkek, 130 $(\% 55,3)$ kadın olmak üzere toplam 235 hastadan oluştu. Hastaların yaşları 18 ile 85 
arasında değişmekteydi ve yaş ortalaması $59,42 \pm 15,18$ idi. Örneklerden 119’u $(\% 50,6)$ Enfeksiyon, 100’ü $(\% 42,6)$ Gastroenteroloji, kalanlar diğer kliniklerden gelmiştir.

Genotip dağılımları; örneklerden 200’ü $(\% 85,1)$ tip 1, 2'si $(\% 0,9)$ tip 2, 20'si $(\% 8,5)$ tip 3, 7'si $(\% 3,0)$ tip 4 ve 6's1 $(\% 2,6)$ mix tip (tip 1a+ tip 1b) idi. Genotip 1 içinde 13’ü $(\% 5,5)$ tip 1a, 182'si $(\% 77,4)$ tip 1 b iken, 5 $(\% 2,1)$ örnekte alt tip belirlenemedi. Grafik $\underline{1}$ 'de genotiplerin yüzdesel olarak dağılım oranları verilmiştir.

Çalışmada hastaların genotip $1 \mathrm{~b}$ olup olmamasına göre değerlendirildiğinde erkeklerin 73'ünde $(\% 69,5)$ kadınların ise 109'unda $(\% 83,3)$ genotip $1 \mathrm{~b}$ saptand1. Kadınlarda genotip $1 \mathrm{~b}$ görülme sıklığ erkeklere göre anlamlı olarak yüksekti $(p=0,009)$. Genotip 1b saptananların yaş ortalaması $62,68 \pm 12,17$ y1l iken diğerlerinin yaş ortalaması $48,23 \pm 18,87$ yıl olarak bulundu. Genotip 1b saptanan hastaların yaş ortalaması diğer genotiplere sahip hastalara göre anlaml olarak yüksekti $(p<0,001)$. Y1llara göre tip1b dağılımında anlamlı bir değişiklik saptanamadı $(\mathrm{p}=0,376),($ Tablo 1).

Yıllara göre HCV genotip dağılımına baktığımızda 2015 yılında toplam 51, 2016 y1lında 102, 2017 y1lında ise 82 örnekte genotip çalışılmıştır. Tüm yıllarda en çok saptanan genotip tip 1, alt tip ise tip 1b olup, tip 2 en az saptanan genotip olmuştur. Mix tip sayısında ise üç yıl içerisinde artış görülmüş̧tür. Tablo 2' de saptanan HCV genotipleri yıllara göre dağılımları verilmiştir.

\section{TARTIŞMA}

HCV genotip dağılımını bilmek, epidemiyolojik verilerin toplanması, aşı geliştirme çalışmaları, tedavi tasarımı ve prognoz açısından önemlidir. Biz de kendi bölgemizde bu verilere katkı sağlamak amacıyla çalışmamızda retrospektif olarak 3 yıllık kayıtları taradık ve HCV genotip dağılımını belirledik.

En s1k görülen genotipin tip 1 olduğu ve vakaların \%85,1'ini oluşturduğu tespit edildi. En sık görülen alt tip ise tip $1 b$ idi. Genel olarak yapılan çalışmalarda ülkemizde de en s1k görülen genotipin genotip $1 \mathrm{~b}$ olduğu bildirilmektedir. Fakat genotip1b'nin görülme yüzdesinin çok değişken olduğu görülmektedir. ${ }^{13-17}$ Altındiş ve arkadaşlarının 7002 kişi üzerinde ve çok merkezli olarak yaptığı bir çalışmada genotip $1 \mathrm{~b}$ görülme sıklığının \%67,7 olduğu bildirilmiştir. ${ }^{14}$ Kırdar ve arkadaşlarının Aydın'da yaptığı bir çalışmada ise genotip 1 sıklığ $1 \% 90,2$ olarak belirtilmiștir. Fakat Kırdar ve arkadaşları genotipleri alt tiplendirme yapmamışlardır. Dolayısıyla bu sıklığın ne kadarının genotip $1 \mathrm{~b}$ olduğu bilinmesede büyük çoğunluğunun genotip $1 b$ olduğu düşünülebilir.

Kayseri ve Nevşehir'de yapılan 3 çalışmada genotip $1 \mathrm{~b}$ görülme sıklığının genel olarak düşük olduğu bildirilmiştir. ${ }^{18-20}$ Kayman ve 
arkadaşlarının Kayseri'de yaptığı çalışmada genotip 1 görülme sıklığ1 \%62,4, Nevşehir'de yapılan çalışmada $\% 37,0$ genotip $1 b$, Kayseri'de yapılan başka bir çalışmada ise $\% 52,7$ genotip $1 \mathrm{~b}$ olduğu rapor edilmiştir. ${ }^{18-20}$ Çok merkezli yapılan çalışmada da bu sonuçlara benzer şekilde Kayseri'den gelen verilerdeki genotip 1b siklığının $\% 60,3$ olduğu

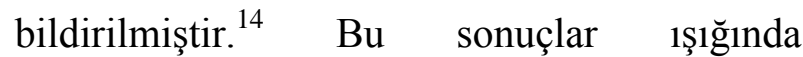
ülkemizdeki HCV genotip dağılımının bölgesel olarak farklılık içerdiği söylenebilir. Çalışmalardaki örneklem sayıları bu sonucu etkilese de bazı bölgelerde genotip dağılımının farklı olabileceği göz önünde bulundurulmalıdır. Ayrica Antalya'da yapılan iki çalışmada genotip $1 \mathrm{~b} \% 63,3$ ve $\% 60,8$ olarak bildirilmiştir. ${ }^{21,22} \mathrm{Bu}$ çalışmaların ikisinde de sonuçlar hastaların uyruğuna göre değerlendirilmiş ve yabancı uyruklularda genotip 3'ün daha sık görüldüğü bildirilmiştir. Çukurova bölgesinde yapılan bir çalışmada Suriye uyruklu olanlarda genotip olarak en s1k genotip 1a, bunu takiben ise genotip 4 tespit edildiği bildirilmiştir. Aynı çalışmada genotip 3'ün en sık damar içi uyuşturucu kullananlarda görüldüğü ifade edilmiştir. ${ }^{23}$ Antalya'da yapılan çalışmalarda yabancı uyrukluların damar içi uyuşturucu kullanımı ile ilgili bilgi verilmemiştir. Marmara bölgesinde yapılan bir çalışmada da genotip 1b'den sonra genotip 3'ün en sik görülen genotip olduğu ve bu hastaların yurtdışı ile ilişkili olduğu tespiti yapılmıştır. $^{24}$ Bizim çalışmamızda da bu çalışmalara benzer şekilde genotip 1'den sonra en fazla genotip 3 bulunmuştur. Fakat biz çalışmamızda hastaları uyruklarına göre veya damar içi madde kullanıp kullanmamalarına göre değerlendirmedik. Bu noktada ülkemize giriş yapan Suriyeli veya diğer mülteciler göz önüne alınarak yapılacak çalışmalarda uyrukların genotip dağılımındaki etkisi ve ayrıca damar içi madde kullanımının da değerlendirilmesi genotip dağılımındaki farklılıkları açıklamada yardımcı olacaktır.

Çalışmamızda kadınlarda ve ileri yaşta olanlarda genotip $1 \mathrm{~b}$ görülme sıklığı anlamlı olarak yüksekti. Yapılan çalışmalarda genotip dağılımı ile cinsiyet ve yaş arasındaki ilişkinin değerlendirilmesinde farklı sonuçlar elde edilmiştir. Bazı çalışmalarda cinsiyet ile genotip dağılımı arasında fark bulunmadığ1 bildirilmiştir. $^{14,21}$ Fakat Kayman ve arkadaşlarının çalışmasında bizim çalışmamıza benzer şekilde genotip 1'in \% 64,5'ini kadınların oluşturduğu rapor edilmiştir. ${ }^{18}$ Yapılan bir çalışmada genotip 1'e sahip olan hastaların sonucumuzla benzer şekilde yaş ortalamasının diğer genotiplere göre daha yüksek olduğu belirtilmiştir. ${ }^{21}$ Çalışmalar arasındaki farklılıkların örneklem hacminden kaynaklanacağı gibi ayrıca kişisel ve bölgesel farklılıklar da sonuçlara etki etmiş olabilir. Genotip değerlendirmesinin yapıldığ 1 çalışmalar genellikle retrospektif olduğundan kayıtlardan kaynaklı bias riski yüksektir. Dolayısıyla prospektif ve analitik çalışmalar 
genotip dağılımındaki farklılıkları ve benzerlikleri açıklamakta çok daha etkili olacaktır.

\section{Sonuç}

Sonuç olarak çalışmamızda; bölgemizdeki örneklerin çoğunluğunda genotip 1, alt tipin ise tip $1 \mathrm{~b}$ olduğu belirlenmiştir. Genotip 1'den sonra en sık, genotip 3 saptanmıştır. Klinik sürecin takibi ve antiviral tedavi seçiminde genotip belirlenmesinin yol gösterici olmasından dolayı bu çalışmaların HCV tedavisine önemli katkıları olacağı düşünülmektedir.

\section{KAYNAKLAR}

1. Lauer GM, Walker BD. Hepatitis C virus infection. New England Journal of Medicine. 2001;345(1):41-52.

2. Hanafiah KM, Groeger J. Global epidemiology of hepatitis $\mathrm{C}$ virus infection: new estimates of age-specific antibody to HCV seroprevalence. Hepatology. 2013;57(4):1333-42.

3. Lozano R, Naghavi M, Foreman K, et al. Global and regional mortality from 235 causes of death for 20 age groups in 1990 and 2010: a systematic analysis for the Global Burden of Disease Study 2010. The Lancet. 2012;380(9859):2095-128.

4. Perz JF, Armstrong GL. The contributions of hepatitis $\mathrm{B}$ virus and hepatitis $\mathrm{C}$ virus infections to cirrhosis and primary liver cancer worldwide. Journal of Hepatology. 2006;45(4):529-38.

5. Timm J, Roggendorf M. Sequence diversity of hepatitis $\mathrm{C}$ virus: implications for immune control and therapy. World Journal of Gastroenterology: WJG. 2007;13(36):4808.

6. Smith DB, Bukh J, Kuiken C, et al. Expanded classification of hepatitis C virus into 7 genotypes and 67 subtypes: updated criteria and genotype assignment web resource. Hepatology. 2014;59(1):318-27.

7. Gower E, Estes C. Global epidemiology and genotype distribution of the hepatitis $\mathrm{C}$ virus infection. Journal of Hepatology. 2014;61(1):S45-S57.

8. Messina JP, Humphreys I, Flaxman A, et al. Global distribution and prevalence of hepatitis C virus genotypes. Hepatology. 2015;61(1):77-87.

9. Mistık R. Hepatit C Virüs enfeksiyonunun epidemiyolojisi. Editörler: Fehmi Tabak, Selma Tosun. Viral Hepatit Kitab1 2014, Viral Hepatitle Savaşım Derneği Yayını, İstanbul tıp Kitabevi 2013, İstanbul 2013; 83-112.

10. Yilmaz Sİ, Erol S. Distribution of viral genotypes and extrahepatic manifestations in patients with chronic hepatitis $\mathrm{C}$ in Eastern Turkey. Turkish Journal of Medical Sciences. 2015;45(1):70-5. 
11. Altuglu I, Soyler I. Distribution of hepatitis $\mathrm{C}$ virus genotypes in patients with chronic hepatitis $\mathrm{C}$ infection in Western Turkey. International Journal of Infectious Diseases. 2008;12(3):239-44.

12. Liver EAFTSOT. EASL Clinical Practice Guidelines: management of hepatitis C virus infection. J hepatol. 2011;55:245-64.

13. Tüzüner U, Saran Gülcen B, Özdemir M, Feyzioğlu B, Baykan M. Seven-year Genotype Distribution Among Hepatitis C Patients in a City in the Central Anatolia Region of Turkey. Viral Hepat J. 2018;24:12-17.

14. Altindis M, Dal T, Akyar I, et al. Six-year distribution pattern of hepatitis $\mathrm{C}$ virus in Turkey: a multicentre study. Biotechnology \& Biotechnological Equipment. 2016;30(2):335-40.

15. Zeytinli ÜO, Yücel FM. Distribution of hepatitis $\mathrm{C}$ virus genotypes in the region of Istanbul Northern Anatolian Association of Public Hospitals. Viral Hepatit Dergisis. 2017;23(1):10.

16. Kirdar S, Aydin N. Dynamics of $\mathrm{HCV}$ epidemiology in Aydin province of Turkey and the associated factors. Apmis. 2018;126(2):109-13.

17. Aktas O, Özbek A. Distribution of HCV genotypes in patients of with chronic hepatitis $\mathrm{C}$ in the eastern anatolia region. Viral Hepatit Dergisi. 2014;20(3).
18. Kayman T, Karakukcu C. Genotypic distribution of hepatitis $\mathrm{C}$ virus infection in Kayseri region. J Turk Mikrobiyol Soc. 2012;42:21-6.

19. Borcak D, Çagır U. Distribution of hepatitis $\mathrm{C}$ virus genotypes and their association with serum alanine aminotransferases and quantitative Serum HCV RNA levels. Journal of Antimicrobial Chemotherapy. 2015;29:36-40.

20. Gökahmetoğlu S, Atalay $M$. Determination of the hepatitis $\mathrm{C}$ virus genotypes with'pyrosequencing'method. Erciyes Medical Journal. 2011;33(2):99102.

21. Sağlik İ, Mutlu D, Öngut $G$, et al. Distribution of hepatitis $\mathrm{C}$ virus genotypes among patients with chronic hepatitis $\mathrm{C}$ infection in Akdeniz University Hospital, Antalya, Turkey: a five-year evaluation. Mikrobiyoloji bulteni. 2014;48(3):429-37.

22. Çekin Y, Gür N. Antalya Eğitim ve Araştırma Hastanesinde kronik Hepatit C hastalarının genotip dağılımının araştırılması. Mikrobiyol Bul. 2014;48(3):484-90.

23. Çetin Duran A, Kibar F. Çukurova Üniversitesi Tıp Fakültesi Hastanesi’nde Hepatit $\mathrm{C}$ virus genotiplerinin ve $\mathrm{HCV}$ enfeksiyonu bulaş yollarının belirlenmesi. Türk Hijyen ve Deneysel Biyoloji Dergisi. 2017;74(3):201-10. 
24. Agca H. Distribution of Hepatitis C Virus Genotypes in the South Marmara Region.
Journal of Clinical and Analytical Medicine. 2014;6(98):190-2. 


\section{HCV GENOTIP DAĞILIM ORANLARI (\%)}

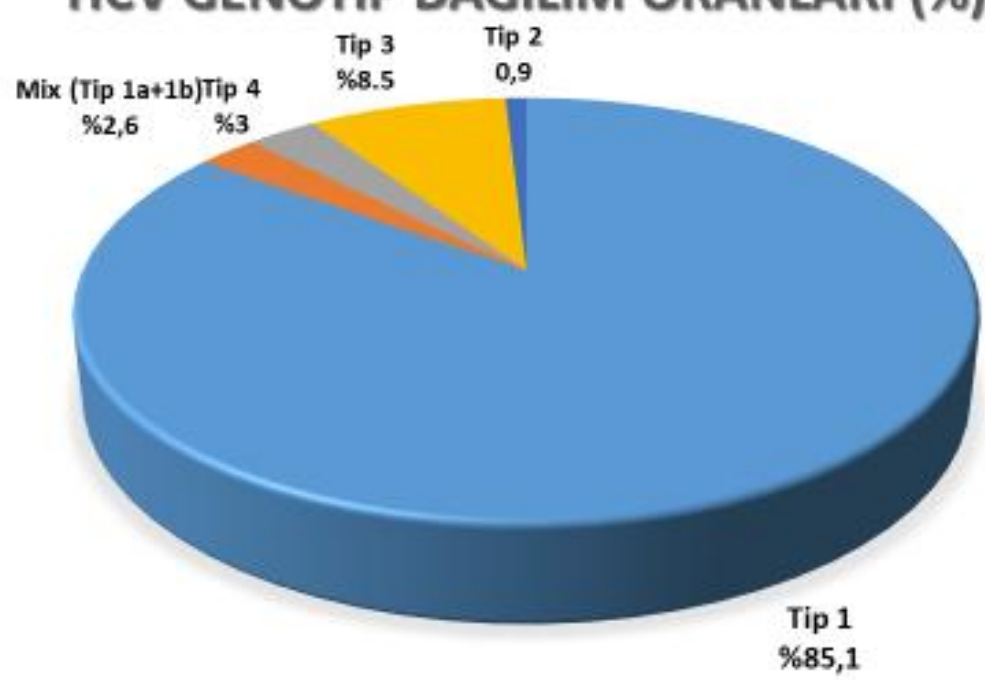

Grafik 1. HCV genotip dağılım oranları (\%) 
Tablo 1. Hastaların genotip $1 b$ olup olmamasına göre değerlendirilmesi ve genotip 1b'nin y1llar içerisindeki dağılımı.

\begin{tabular}{llll}
\hline & $\begin{array}{l}\text { Genotip 1b olanlar } \\
\mathbf{n = 1 8 2}\end{array}$ & $\begin{array}{l}\text { Diğer genotipler } \\
\mathbf{n = 5 3}\end{array}$ & $\mathbf{p}$ \\
$\begin{array}{l}\text { Cinsiyet, } \mathbf{n}(\%) \\
\text { Erkek }\end{array}$ & $73(69.5)$ & $32(30.5)$ & 0.009 \\
Kadın & $109(83.5)$ & $21(16.2)$ & \\
Yaş, ortalama \pm SS $^{*}$ & $62.68 \pm 12.17$ & $48.23 \pm 18.87$ & $<0.001$ \\
Yıllar, $\mathbf{n}(\%)$ & & & \\
2015 & $34(75.6)$ & $11(24.4)$ & 0.376 \\
2016 & $88(81.5)$ & $20(18.5)$ & \\
2017 & $60(73.2)$ & $22(26.8)$ & \\
\hline
\end{tabular}

*: Standart sapma 
Tablo 2. Saptanan HCV Genotipleri ve Y1llara Göre Dağ̊lımı.

\begin{tabular}{lllllllllll}
\hline \multicolumn{9}{c}{ Saptanan Genotipler } & \multicolumn{1}{l}{ Tip } \\
\cline { 1 - 2 } & Tip 1* & Tip & Tip & Tip & Tip & Tip & Tip & Tip 4* & Mix Tip & Toplam \\
$\mathbf{2 0 1 5}$ & & $\mathbf{1 a}$ & $\mathbf{1 b}$ & $\mathbf{2 a}$ & $\mathbf{2 b}$ & $\mathbf{3 a}$ & $\mathbf{4 a}$ & & & Sayı \\
$\mathbf{2 0 1 6}$ & 0 & 3 & 39 & 0 & 1 & 7 & 0 & 1 & 0 & 51 \\
$\mathbf{2 0 1 7}$ & 0 & 8 & 83 & 1 & 0 & 6 & 3 & 0 & 1 & 102 \\
Toplam alttip & 5 & 2 & 60 & 0 & 0 & 7 & 0 & 3 & 5 & 82 \\
Toplam genotip & 200 & 13 & 182 & 1 & 1 & 20 & 3 & 4 & 6 & 235 \\
\hline
\end{tabular}

*Alt tiplendirme yapılamamıştır. 